\title{
A comparison of citrulline and arginine for increasing exercise-induced vasodilation and blood flow
}

\author{
Jordan R Moon ${ }^{1,2^{*}}$, Roxanne M Vogel ${ }^{1,3}$, Paul H Falcone ${ }^{1}$, Matt M Mosman', Aaron C Tribby ${ }^{1}$, Chad M Hughes ${ }^{4}$, \\ Jonathan D Griffin ${ }^{5}$, Schyler B Tabor ${ }^{6}$, Dylan J LeFever ${ }^{7}$, Stephen B McChaughey ${ }^{7}$, Michael P Kim7, Jordan M Joy ${ }^{1,3}$
}

From The Twelfth International Society of Sports Nutrition (ISSN) Conference and Expo

Austin, TX, USA. 11-13 June 2015

\section{Background}

One goal of supplementation has been to increase blood flow to skeletal muscle during exercise. Raw L-citrulline $(\mathrm{RC})$ and raw L-arginine (RA) has often been used for its vasodilatory effects, and recently, citrulline and arginine have been bound to a whey peptide $(\mathrm{CP}$ and $\mathrm{AP}$, respectively) to increase bioavailability. The purpose of the present study was to compare the acute hemodynamic effects of RC, CP, RA, and AP following resistance exercise in healthy, men when administered at a common, commercial dose.

\section{Methods}

In a double-blind, crossover, placebo-controlled design, 11 recreationally-active males $(28.2 \pm 5.0 \mathrm{y}, 182.4 \pm 5.7 \mathrm{~cm}$, $87.1 \pm 10.3 \mathrm{~kg}$ ) ingested either $1.87 \mathrm{~g}$ of $\mathrm{RC}, 3.67 \mathrm{~g}$ of CP (citrulline content $1.87 \mathrm{~g}$ ), $1.87 \mathrm{~g}$ of RA, or $3.07 \mathrm{~g}$ of AP (arginine content $1.87 \mathrm{~g}$ ) and performed 3 sets of 15 arm curls at 30 and 120 minutes post-supplementation. Brachial artery vessel diameter (VD) and blood flow volume (BFV) were measured via Doppler ultrasound at 0 , 3 , and 6 minutes post-exercise, corresponding to 30 (30P), 33 (33P), 36 (36P), 120 (120P), 123 (123P), and 126 (126P) minutes post-supplementation. Measurements were compared with both resting baseline (no treatment, no exercise) and active control (no treatment, exercise) values. Raw data were analyzed for all group, time, and group $\times$ time interactions using 2-way repeated-measures ANOVA. Delta values were analyzed using dependent T-tests. Alpha was predetermined at $\mathrm{p}<0.05$.

* Correspondence: jordan@musclepharm.com

${ }^{1}$ MusclePharm Sports Science Institute, Denver, CO, USA

Full list of author information is available at the end of the article

\section{Results}

A significant $(\mathrm{p}<0.05)$ group $\times$ time effect was present for VD, which significantly increased in CP versus RA from active baseline to 33P (CP: $0.57 \pm 0.05$; RA: $0.55 \pm$ $0.05 \mathrm{~cm})$. Although, no effects for BFV were observed ( $p>0.05)$. No differences were found between delta values for $\mathrm{CP}$ and $\mathrm{AP}$ nor between delta values for RC and RA or AP for VD ( $\mathrm{p}>0.05)$. However, VD delta values for $\mathrm{CP}$ were significantly $(\mathrm{p}<0.05)$ greater than for RA at 33P $(\mathrm{CP}:+0.04 \pm 0.03$; RA: $+0.02 \pm 0.02 \mathrm{~cm})$ and 36P $(\mathrm{CP}:+0.04 \pm 0.02 ;+0.02 \pm 0.02 \mathrm{~cm})$ compared to active controls. A significantly $(\mathrm{p}<0.05)$ greater change in BFV for the $\mathrm{CP}$ and $\mathrm{RC}$ treatments versus the RA treatment were observed at 33P $(\mathrm{CP}:+62.6 \pm 155.8$; RC: $+57.6 \pm 145.3$; RA: $-26.4 \pm 137.4 \mathrm{~mL} / \mathrm{min})$ compared to active control values. Conversely, significantly ( $\mathrm{p}<$ $0.05)$ greater delta values for BFV were observed for AP over CP at $126 \mathrm{P}$ (AP: $-5.6 \pm 90.8$; CP: $-50.2 \pm$ $74.7 \mathrm{~mL} / \mathrm{min}$ ) compared to active controls.

\section{Conclusions}

Collectively, citrulline-based ingredients appear to be more effective than arginine-based ingredients for modulating vasodilation and blood flow. The whey peptide bound state may positively influence the effects of supplementation.

\footnotetext{
Authors' details

'MusclePharm Sports Science Institute, Denver, CO, USA. ²Department of Sports Exercise Science, United States Sports Academy, Daphne, AL, USA. ${ }^{3}$ Department of Human Performance, Concordia University Chicago, River Forest, IL, USA. ${ }^{4}$ Department of Movement Science, Grand Valley State University, Allendale, MI, USA. ${ }^{5}$ Department of Biomedical Engineering, Widener University, Chester, PA, USA. ${ }^{6}$ The Hospitality College, Johnson and
} 
Wales University, Denver, CO, USA. 'Department of Human Performance and Sport, Metropolitan State University, Denver, CO, USA.

Published: 21 September 2015

doi:10.1186/1550-2783-12-S1-P6

Cite this article as: Moon et al:: A comparison of citrulline and arginine

for increasing exercise-induced vasodilation and blood flow. Journal of the International Society of Sports Nutrition 2015 12(Suppl 1):P6.

Submit your next manuscript to BioMed Central and take full advantage of:

- Convenient online submission

- Thorough peer review

- No space constraints or color figure charges

- Immediate publication on acceptance

- Inclusion in PubMed, CAS, Scopus and Google Scholar

- Research which is freely available for redistribution 